\title{
STRENGTHS AND LIMITATIONS OF OPEN EDUCATIONAL RESOURCES TO ADVANCE COPYRIGHT LITERACY (Paper)
}

\begin{abstract}
Résumé:
The proposed paper explores challenges associated with the creation of open educational resources (OER) for Canadian copyright education. Tensions include modeling best practices for open content licensing in copyright-related material, balancing narrative engagement with precise information on a complex subject, creating content for multiple audiences, and the use of open tools for the creation of accessible, adaptable materials. This case study outlines tactics for addressing these tensions, such as balancing a commitment to openness with a focus on engagement, discovery of easy-to-use multimedia tools for adding interactivity, and embracing perspectives outside legal and academic experts during content creation.
\end{abstract}

\section{Introduction}

Over the past 15 years open educational resources (OER) have emerged as an increasingly common vehicle for teaching and learning, also providing a platform for broader public access and engagement. Discourse on OER specifically emphasizes how such resources can enable lifelong learning by those outside academia and democratize access to knowledge (UNESCO, n.d.; OECD, 2007, 9). However, critical literature on OER has identified a number of practical limitations on the promise of increased access to knowledge (Almeida, 2017; Ameil, 2012; Crissinger, 2015; and, Weiland, 2015).

During this same time period there has been growing emphasis on the importance of copyright literacy (Burkell et al., 2015, ii; Morrison, 2018, 97; Benson, 2019(f)). Concomitantly, copyright literacy remains a core competency for library and information science (LIS) professionals and students (ALA, 2009, 2; IFLA, 2018), and a sought-after skill by LIS employers (SJSU, 2018, 14). However, in the Canadian context, there are few opportunities for copyright education for LIS students (Patterson, 2016, 5), faculty members in all disciplines (Zerkee, 2016, 8; Di Valentino, 2015, 8), and the general Canadian public (Murray, 2004, n. 2). Furthermore, and in keeping with the structure of the legislation, existing copyright education is largely framed around the needs of rights-holders, not users (McGill, 2019; WIPO, n.d.; Harris,2018). Thus, there is a gap in copyright-education opportunities in Canada.

Given the importance of copyright to LIS students and professionals, academics in general, and the broader public, OER that promote copyright literacy appear to be an ideal solution to the copyright education gap. Unfortunately, the simple alignment of subject matter (copyright) and mode of delivery (OER) is complicated by a variety of factors.

The proposed paper problematizes copyright education through OER and is framed by the broader research problem of how OER can be used to advance copyright education. Through a critical study of the University of X's ${ }^{\mathrm{i}}$ grant-funded Opening Up Copyright Instructional module 
series, the proposed paper examines what limitations subject matter (copyright) and openness impose on the creation of engaging learning resources.

\section{Literature Review and Context}

The proposed paper is informed and framed by literature on engagement and best practices in the design of instructional videos/tutorials and literature on the strengths and limitations of copyright education in Canada.

\section{Engagement in Instructional Videos}

The extensive literature on online information literacy instruction is replete with best practices for the creation of online videos. Common considerations include: having learning objectives (Evans, 2014, 14; Weeks and Davis, 2017, 185; Lo and Dale, 2009, 151); keeping videos to a short length with common suggestions that length be no more than three minutes (Evans, 2014, 14; Weeks and Davis, 2017, 186; Martin and Martin, 2015, 48); using scripts (Weeks and Davis, 2017, 185; Clossen, 2014, 34); including interactivity (Lo and Dale, 2009, 151; Martin and Martin, 2015, 47; Smith, 2010, 151); minimizing cognitive overload through chunking and avoiding jargon (Weeks and Davis, 2017, 186; Lo and Dale, 2009, 151; Martin and Martin, 2015, 48; Clossen, 2014, 34; Smith, 2010, 154); ensuring narration is in a conversational tone (Martin and Martin, 2015, 52); avoiding large blocks of text on screen (Clossen, 2014, 34); making content available in multiple formats and ensuring accessibility (Weeks and Davis, 2017, 186; Martin and Martin, 2015, 50; Courtney and Wilhoite-Mathews, 2015, 273); and, where possible, forming collaborations that include librarians, faculty, and instructional designers (Lo and Dale, 2009, 152).

\section{Copyright Education in Canada}

Several recent studies have assessed the state of copyright literacy and education within higher education contexts in Canada. Patterson $(2016,4)$ notes that the overwhelming majority of copyright officers and librarians in Canada have LIS education backgrounds, but often lack formal training in their education in copyright due to a general lack of copyright-specific courses offered by LIS programs in Canada (5). Di Valentino (2015, 6 and 8) found that many faculty members are unaware of the availability of copyright training from their own institutions, and that those who were aware often failed to attend any training on the subject. Similarly, Zerkee $(2016,8)$ reveals that copyright instruction is rarely required for instructors, staff or students at Canadian post-secondary institutions. Furthermore, she found that interactive tutorials on copyright were only offered by 3 of the 22 institutions surveyed ( 8 and 15). Finally, Winter et al. (2017) note a range of approaches to copyright literacy around the world, including the Open Education and Licensing Toolkit in Australia, the "Copyright Literacy for Ontario College Employees" series, and the UK-based "Copyright the Card Game," which has recently been adopted into a Canadian version (Secker, 2018).

Despite an extensive body of literature on online video resource creation and an emergent body of literature on copyright education in Canada, there is a lack of studies examining Canadian cases where online videos are used to advance copyright literacy for multiple audiences.

\section{Methodology}


The proposed paper is a case study of the University of X's Opening Up Copyright instructional module series. Case studies are particularly well-suited for the study of individual programs or initiatives (Leedy and Ormrod, 2005, 135). While single case studies may have limited generalizability, they can be particularly well-suited to examining causal relationships (Gary, 2004, 124-5). While single case studies do suffer from limitations and concerns around selection biases, they can prove useful when chosen to focus on unusual cases (Flyvberg, 2004, 396).

Finally, while proximity to the case may be a source of bias, it is important to note that Flyvberg $(2004,399)$ suggests that this kind of proximity also enables advanced understanding if undertaken critically.

\section{Findings and Discussion}

Critical reflection on the University of X's Opening Up Copyright instructional module series reveals several important tensions surrounding engagement that result from both subject matter and the creation of openly licensed materials.

\section{Tension between Narrative and Exactitude}

Narrative is a key element for facilitating engagement in online videos as stories are more compelling than summaries of facts. While the importance of narrative has been stressed within the project team, subject matter, and in particular the need for exactness and detail in dealing with copyright issues, precludes some degree of narrativization. For example, in modules on copyright issues commonly faced in everyday academic contexts (working with images) narratives are easier to integrate into the modules. However, it is much more challenging to use narrative to teach about specific sections of the Copyright Act. While the project has generally aligned itself with the best practices identified in the literature, the level of detail required for discussing examples in copyright, particularly jurisprudence, results in videos longer than three minutes.

A second challenge created by the need for exactitude is requirement that modules be carefully scripted. The scripting of modules is necessary to ensure that they meet the requirements of the project team, which includes a faculty member, the Copyright Librarian and the Director of the Copyright Office. However, the result has been that the narration of the videos is, to a degree, stilted, and as such less engaging for the audience.

\section{Adaptability and openness create barriers to engagement}

The most important insights to date from the project relates to the tension produced betwixt the development of engaging modules for broad audiences and the requirements of OER open licensing. In order to develop OER, the project team was precluded from using common proprietary software and commercial animation programs that are commonly used to produce online instructional videos. While open source software animation platforms exist and were evaluated by the project team at the start of the project, it was determined that the technical skill required to effectively create videos using these platforms was so demanding that it effectively undermined the benefits of being open. Specifically, if others wanted to adapt the videos created using these open source platforms, the level of skill required to do so would serve as a high barrier to adaptation. Another challenge encountered during the project was related to third party content. Having to rely on content with a compatible open licence significantly limited the amount of source content that could be incorporated into the modules. While reliance on fair 
dealing would allow for a greater range of materials to be incorporated into the video, the emphasis on open licensing has circumscribed the project team's ability to use content that is not permissively licensed (i.e. CC open culture licences).

Despite the challenges faced, the project team has developed insights on a range of techniques and approaches to help address these concerns. With regards to openness, a realization was made early on that maximal openness was not always possible, and as such a small share of the overall number of modules are developed using a commercial animation suite to facilitate higher levels of engagement with modules that are perceived to be of the greatest interest to the broadest range of users. The H5P collaboration framework has proven an effective means to add interactivity to videos without limiting openness. With regards to script development, while copyright expertise still forms the basis around which scripts are created, the inclusion of outside skills, specifically students with theatre / performance backgrounds, appears an effective means to improve engagement.

\section{Conclusion}

The proposed paper provides important insights about the limitations of knowledge translation, particularly on a relatively dry subject matter like copyright and engagement with audiences both inside and outside of academia. The paper demonstrates that despite the process of developing OER is constrained by a variety of factors, and that openness itself is a barrier to translating knowledge outside of the academy. In addition, the presentation will demonstrate selected highlights from various modules, and expand on the limitations imposed by designing for multiple audiences, which due to space considerations are not expanded upon in the abstract. The proposed paper is aligned with conference sub themes of outreach and knowledge translation. Attendees will gain insights on strategies for the development of effective OER and approaches to fostering copyright literacy.

\section{Reference List}

Almeida, Nora. 2017. "Open Educational Resources and Rhetoric Paradox in the Neoliberal Univers(ity)." Journal of Critical Library and Information Studies, 1: 1-19.

Ameil, Tel. 2012. "Identifying Barriers to the Remix of Translated Open Educational Resources." International Review of Research in Open and Distance Learning, 14(1): p. 16-144.

American Library Association (ALA). 2009. ALA's Core Competencies of Librarianship. http://www.ala.org/educationcareers/sites/ala.org.educationcareers/files/content/careers/c orecomp/corecompetences/finalcorecompstat09.pdf

Benson, Sara Rachel. 2019 (forthcoming). Copyright Conversations: Rights Literacy in a Digital World. ACRL Press.

Burkell, Jacquelyn, A., Alexandre Fortier, Lisa Di Valentino, and Sara T. Roberts. 2015. Enhancing Key Digital Literacy Skills: Information Privacy, Information Security, and Copyright/Intellectual Property. https://ir.lib.uwo.ca/cgi/viewcontent.cgi?article=1038\&context=fimspub

Clossen, Amanda S. 2014. "Beyond the Letter of the Law: Accessibility, Universal Design and Human-Centered Design in Video Tutorials." Pennsylvania Libraries: Research \& Practice, 2(1): 27-37. 
Courtney, Michael, and Sara Wilhoite-Mathews. 2015. "From Distance Education to Online Learning: Practical Approaches to Information Literacy Instruction and Collaborative Learning in Online Environments." Journal of Library Administration, 55: 261-277.

Crissinger, Sarah. 2015. "A Critical Take on OER Practices: Interrogating Commercialization, Colonialism and Content." In the Library with the Lead Pipe. (Oct 21 2015): http://www.inthelibrarywiththeleadpipe.org/2015/a-critical-take-on-oer-practicesinterrogating-commercialization-colonialism-and-content/

Di Valentino, Lisa. 2015. Awareness and Perception of Copyright among Teaching Faculty at Canadian Universities. https://ir.lib.uwo.ca/cgi/viewcontent.cgi?article=1040\&context=fimspub

Evans, Rachel. 2014. "Cooking Up Cauldrons of Content: Recipes for Video Tutorials.” Articles, Chapters and Online Publications. 32. https://digitalcommons.law.uga.edu/law_lib_artchop/32

Flyvberg, Bent. 2004. "Five Misunderstandings About Case-Study Research." p. 390-404. In Qualitative Research Practice. Clive Seale et al. (Eds.). London: Sage.

Gray, David E. 2004. Doing Research in the Real World. London: Sage.

Harris, Lesley Ellen. 2018. "Home." Copyrightlaws.com https://www.copyrightlaws.com/ International Federation of Library Associations and Institutions (IFLA). 2018. IFLA Statement on Copyright Education and Copyright Literacy. https://www.ifla.org/publications/node/67342

Leedy, Paul D., and Jeanne Ellis Ormrod. 2005. Practical Research: Planning and Design. Upper Saddle River, NJ: Pearson.

Lo, Leo S., and Jenny McCraw Dale. 2009. "Information Literacy 'Learning' via Online Tutorials: A Collaboration between Subject Specialist and Instructional Design Librarian." Journal of Library and Information Services in Distance Learning, 3: 148158.

Martin, Nichole A., and Ross Martin. 2015. "Would You Watch It? Creating Effective and Engaging Video Tutorials." Journal of Library and Information Services in Distance Learning, 9: 40-56.

McGill University - School of Continuing Studies (McGill). 2019. "Intellectual Property." https://www.mcgill.ca/continuingstudies/area-of-study/intellectual-property

Morrison, Chris. 2018. "Copyright and Digital Literacy: Rules, Risk and Creativity." p. 97-108. In Digital Literacy Unpacked. Katharine Reedy and Jo Parker (Eds.). London, Facet. https://kar.kent.ac.uk/70446/1/Morrison\%20$\% 20$ Copyright $\% 20$ and $\% 20$ digital $\% 20$ literacy\%20\%20rules $\% 2 \mathrm{C} \% 20$ risk\%20and\%20creativity\%20\%28in\%20Reedy\%20and\%20Parker\%2 C\%20Digital\%20Literacy\%20Unpacked\%29.pdf

Murray, Laura J. 2004. "Protecting Ourselves to Death: Canada, Copyright and the Internet." First Monday, 9(10): https://journals.uic.edu/ojs/index.php/fm/article/view/1179/1099

Organisation for Economic Cooperation and Development (OECD). 2007. Giving Knowledge For Free. http://www.oecd.org/education/ceri/38654317.pdf

Patterson, Erin. 2016. "The Canadian University Copyright Specialist: A Cross-Canada Selfie." Partnership, 11(2): http://dx.doi.org/10.21083/partnership.v11i2.3856

San Jose State University - School of Information (SJSU). 2018. MLIS Skills at Work: A Snapshot of Job Postings: Spring 2018. https://ischool.sjsu.edu/sites/main/files/fileattachments/career_trends.pdf 
Secker, Jane. 2018. "Copyright the Card Game - A Report from the Canadian Contingent." UK Copyright Literacy. 1 Jul. 2018. https://copyrightliteracy.org/2018/07/01/copyright-thecard-game-a-report-from-the-canadian-contingent/

Smith, Susan Sharpless. 2010. Web-Based Instruction: A Guide for Libraries. 3rd Ed. Chicago: American Library Association.

United Nations Educational, Scientific and Cultural Organization (UNESCO). N.d. "Open Educatoinal Resourcse.” https://en.unesco.org/themes/building-knowledge-societies/oer

Weeks, Thomas and Jennifer Putnam Davis. 2017. "Evaluating Best Practices for Video Tutorials: A Case Study." Journal of Library and Information Services in Distance Learning, 11(1-2): 183-195.

Weiland, Steven. 2015. "Open Educational Resources: American Ideals, Global Questions." Global Education Review, 2(3): 4-22.

Winter, Christina, Brad Doerksen, Kate Langrell, and Tasha Maddison. 2017. "Copyright Education, Copyright Literacy and Information Literacy." Presented at the ABC Copyright Conference, 30 Jun. 2017. Queen's University, Kingston, ON, Canada. https://qspace.library.queensu.ca/bitstream/handle/1974/22021/Copyright\%20Education $\% 252 \mathrm{c} \% 20$ Institutional\%20Literacy\%20\%26\%20Information\%20Literacy.pdf?sequence $=1 \&$ is Allowed $=\mathrm{y}$

World Intellectual Property Organization (WIPO). N.d. "WIPO Academy." https://www.wipo.int/academy/en/

Zerkee, Jennifer. 2016. "Approaches to Copyright Education for Faculty in Canada." Partnership, 11(2): http://dx.doi.org/10.21083/partnership.v11i2.3794

' Blinded for review purposes 